ANALISIS PENGETAHUAN NASABAH TENTANG PRODUK PERBANKAN SYARIAH (Studi pada Bank Muamalat KCP Malang Kepanjen)

\author{
Rosyidah, Muhammad Nizar, Khoirul Huda \\ Rda011132@gmail.com,muhammadnizar@yudharta.ac.id, \\ khoirulhuda@yudharta.ac.id \\ Universitas Yudharta Pasuruan
}

\begin{abstract}
Banks are not something that is alien to people in developed countries. People in developed countries really need the existence of a bank. The bank is considered a financial institution that is safe in carrying out various types of financial activities. Islamic banks are developed based on principles that do not allow separation between temporal and religious matters. This principle requires compliance with sharia as the basis of all aspects of life. This report addresses the problem of the level of knowledge of customers about Islamic banking products at Bank Muamalat, Kepanjen Sub-Branch Office Malang. This study uses a quantitative method from the results of observation, practice and spread the questionnaire to the customers of Bank Muamalat, Kepanjen Sub-Branch Office Malang. The results of the analysis show that the customer's knowledge of the product is higher than the customer's knowledge about buying and using. While customer knowledge about purchases is lower than customer knowledge about products and usage. In addition, customer knowledge has a positive and significant effect on the decision to become a customer at Bank Muamalat, Kepanjen Malang SubBranch Office.
\end{abstract}

Keywords: Knowledge, Customers, Islamic Banking Products.

\title{
PENDAHULUAN
}

Bank bukanlah suatu hal yang asing bagi masyarakat di negara maju. Masyarakat di negara maju sangat membutuhkan keberadaan bank. Bank dianggap sebagai suatu lembaga keuangan yang aman dalam melakukan berbagai macam aktivitas keuangan. Bank merupakan salah satu lembaga yang mempunyai peran penting dalam mendorong pertumbuhan perekonomian suatu negara, bahkan pertumbuhan bank di suatu Negara 
dipakai sebagai ukuran pertumbuhan perekonomian negara tersebut. ${ }^{1}$ Layaknya dalam suatu perekonomian apapun sistem ekonomi yang dipakai hubungan antara pihak yang melakukan kegiatan ekonomi akan berakhir dengan transaksi. Dalam sistem ekonomi yang berparadigma Islam, transaksi senantiasa harus dilandasi oleh aturan hukum Islam. ${ }^{2}$

Perbankan Islam memberikan layanan bebas bunga kepada para nasabahnya. Pembayaran dan penarikan bunga dilarang dalam semua bentuk transaksi. Islam melarang kaum muslimin menarik atau membayar bunga (riba). Pelarangan inilah yang membedakan sistem perbankan Islam dengan sistem perbankan konvensional. Secara teknis, riba adalah tambahan pada jumlah pokok pinjaman dan jumlah pinjamannya. ${ }^{3}$ Bank-bank Islam dikembangkan berdasarkan prinsip yang tidak membolehkan pemisahan antara hal yang temporal (keduniaan) dan keagamaan. Prinsip ini mengharuskan kepatuhan kepada syariah sebagai dasar dari semua aspek kehidupan. ${ }^{4}$ Secara teori bank syariah menggunakan konsep two tier mudharabah (mudharabah dua tingkat), dimana bank syariah berfungsi dan beroperasi sebagai institusi intermediasi investasi yang menggunakan akad mudharabah pada kegiatan pendanaan (pasiva) maupun pembiayaan (aktiva). Dalam pendanaan bank syariah bertindak sebagai pengusaha (mudharib), sedangkan dalam pembiayaan bank syariah bertindak sebagai pemilik dana (shahibul maal). Selain itu, bank syariah juga dapat bertindak sebagai agen investasi yang mempertemukan pemilik dana dan pengusaha. ${ }^{5}$

Dengan demikian operasionalisasi perbankan syariah semakin luas. Sekarang titik kulminasi telah tercapai dengan disahkannya UU No.10 tahun 1998 tentang perbankan yang membuka kesempatan bagi siapa saja yang akan mendirikan bank syariah maupun yang ingin mengkonversikan dari sistem konvensional menjadi sistem bagi hasil. ${ }^{6}$ Di Kepanjen Malang Perbankan Syariah sudah mulai berkembang, terbukti dengan adanya Bank Muamalat ini. Dengan berkembangnya bank-bank syariah di Kepanjen

\footnotetext{
${ }^{1}$ Ismail, Manajemen Perbankan Dari Teori Menuju Aplikasi, (Jakarta: Kencana, 2010), h.1

2 Selamet Wiyono, Cara Mudah Memahami Akuntasi Syariah, (Jakarta: PT Gramedia Widiasarana Indonesia, 2005), h.25

${ }^{3}$ Latifa M. Alqaoud dan Mervyn K. Lewis, Perbankan Syariah, (Jakarta: PT Serambi Ilmu Semesta, 2001), h.11

${ }^{4}$ Muhammad Syafi'I Antonio, Bank Syariah Dari Teori Ke Praktek, (Jakarta: Gema Insani Press, 2001), h.200

${ }_{6}^{5}$ Ascarya, Akad \& Produk Bank Syariah, (Jakarta: PT RajaGrafindo Persada, 2008), h.31

${ }^{6}$ Mawardi, Ekonomi Islam, (Pekanbaru: Alaf Riau, 2007), h.23
} 
menandai akan semakin luas lagi perkembangan perbankan syariah di Indonesia. Pada umumnya bank syariah sudah banyak diminati masyarakat terutama pada masyarakat Kepanjen.

Jadi, untuk meningkatkan perbankan syariah di Kepanjen ataupun dikalangan masyarakat supaya bank syariah lebih dikenal dan lebih unggul atau maju di mata mereka, perlu adanya usaha yang kuat dari pihak perbankan syariah selain dari harus promosi yang baik juga harus merubah pandangan masyarakat tentang bank syariah selama ini. Mengingat dengan perkembangan bank syariah di Kepanjen, maka sejauh mana tingkat pengetahuan masyarakat mengetahui dan memahami produk-produk bank syariah terutama yang berada di Kepanjen.

\section{KAJIAN TEORI}

\section{Pengetahuan Nasabah}

Pengetahuan merupakan suatu pembelajaran yang diperoleh seseorang dari sebuah pengalaman. Pengetahuan nasabah merupakan informasi yang disimpan oleh nasabah dalam benak ingatan. Pengetahuan adalah hasil penginderaan manusia yang diperoleh dari pengalaman hidupnya, yang menjadi acuan dalam pembentukan sikap seseorang. Pengetahuan dipengaruhi oleh beberapa faktor seperti pengalaman, pendidikan, keyakinan, sosial, lingkungan dan sebagainya. Pengetahuan (Knowledge) adalah informasi yang diberikan kepada seseorang subjek mengenai kebenaran atau ketepatan reaksinya. Prinsip penting dari jenis belajar ini menyatakan bahwa mempelajari asosiasi bisa dipermudah dengan jalan memberikan kepada orang yang tengah belajar itu informasi mengenai kemajuannya, baik segera setelah ia membuat pilihan atau pada akhir satu seri pilihannya. ${ }^{7}$

\section{Produk Perbankan Syariah}

Pada sistem operasi Bank Syariah, pemilik dana menanamkan uangnya di bank tidak dengan motif mendapatkan bunga, tetapi dalam rangka mendapatkan keuntungan bagi hasil. Dana nasabah tersebut kemudian disalurkan kepada mereka yang membutuhkan (misalnya modal usaha) dengan perjanjian pembagian keuntungan sesuai kesepakatan. Pembiayaan dalam perbankan syariah tidak bersifat menjual uang yang

\footnotetext{
${ }^{7}$ Andrian Sutedi, Pasar Modal Syariah (Jakarta: Sinar Grafika, 2011), h. 121.
}

..::: Malia: Jurnal Ekonomi Islam, Volume 10 Nomor 2 Juni 2019 :::... 
$166\}\{$ Analisis Pengetahuan Nasabah tentang Produk Perbankan Syariah

mengandalkan pendapatan bunga atas pokok pinjaman yang diinvestasikan, tetapi dari pembagian laba yang diperoleh pengusaha. Pendekatan bank syariah mirip dengan invesment banking, di mana secara garis besar produk adalah mudharabah (trust financing) dan musyarakah (partnership financing), sedangkan yang bersifat investasi diimplementasikan dalam bentuk murabahah (jual beli). ${ }^{8}$ Pada dasarnya, produk yang ditawarkan oleh Bank Syariah dapat dibagikan menjadi tiga bagian besar, yaitu:

a. Produk penghimpun dana (Funding)

1) Giro Wadiah adalah produk pendanaan bank syariah berupa simpanan dari nasabah dalam bentuk rekening giro untuk keamanan dan kemudahan pemakainnya.

a) Wadiah yad Amanah adalah titipan dimana barang yang dititipkan sama sekali tidak boleh digunakan oleh pihak yang menerima titipan.

b) Wadiah yad Dhamanah adalah titipan yang mana terhadap barang yang dititipkan tersebut dapat digunakan atau dimanfaatkan oleh penerima titipan.

2) Tabungan adalah simpanan yang penarikannya hanya dapat dilakukan menurut syarat tertentu yang disepakati, tetapi tidak dapat ditarik dengan cek, bilyet, giro dan atau alat lainnya.

3) Deposito adalah produk dari bank yang memang ditunjuk untuk kepentingan investasi dalam bentuk surat-surat berharga, sehingga dalam perbankan syariah akan memakai prinsip mudharabah.

b. Produk penyaluran dana (Lending)

1) Pembiayaan dengan prinsip jual beli

a) Pembiayaan Murabahah adalah transaksi jual beli dimana bank menyebut jumlah keuntungannya.

b) Pembiayaan salam adalah transaksi jual beli dimana barang dijualbelikan belum ada.

c) Pembiayaan Istishna' adalah produk istishna' yang menyerupai salam tetapi istishna' pembayaranya dapat dilakukan oleh bank beberapa kali (cicilan). ${ }^{9}$

8 Amir Machmud, Rukmana, Bank Syariah Teori, Kebijakan, Dan Studi di Indonesia,(Jakarta: Gelora Aksara Pratama, 2010), h. 28

9 Adiwarman A. Karim, Bank Islam Analisa Fiqih Dan Keuangan, (Jakarta: PT RajaGrafindo Pers, September 2004), h. 90

..:::: Malia: Jurnal Ekonomi Islam, Volume 10 Nomor 2 Juni 2019 :::.. 
2) Pembiayaan dengan prinsip ijarah

Transaksi ijarah dilandasi adanya pemindahan manfaat. Jadi pada dasarnya prinsip ijarah sama saja dengan prinsip jual beli, tapi perbedaannya terletak pada objek transaksinya. Bila pada jual beli objek transaksinya adalah barang, pada ijarah objek transaksinya adalah jasa.

3) Pembiayaan dengan prinsip bagi hasil

a) Pembiayaan Musyarakah adalah transaksi yang dilandasi adanya keinginan para pihak yang bekerjasama untuk meningkatkan nilai aset yang mereka miliki secara bersamasama.

b) Pembiayaan Mudharabah adalah bentuk kerjasama antara dua orang atau lebih, dimana pihak pemilik modal menyediakan seluruh modal, sedangkan pihak lainnya menjadi pengelolah.

c) Pembiayaan Al-Muzaro'ah adalah kerjasama pengelolahan pertanian antara pemilik lahan dan penggarap, dimana pemilik lahan memberikan lahan pertanian kepada si penggarap untuk ditanami dan dipelihara dengan imbalan bagian tertentu (persentase) dari hasil panen.

d) Pembiayaan Al-Musaqoh adalah bentuk yang lebih sederhana dari muzaro'ah dimana si penggarap hanya bertanggung jawab atas penyiraman dan pemeliharaan.

4) Pembiayaan degan akad pelengkap

a) Hiwalah adalah membantu supplier mendapatkan modal tunai agar dapat melanjutkan produksinya.

b) Rahn adalah menahan salah satu harta milik si peminjam sebagai jamian atas pinjaman yang diterimanya.

c) Qard adalah pemberian harta kepada orang lain yang dapat ditagih atau dapat diminta kembali atau dengan kata lain meminjamkan tanpa mengharapkan imbalan. ${ }^{10}$

d) Wakalah adalah pelimpahan kekuasaan oleh seseorang kepada orang lain dalam hal yang diwakilkan.

e) Kafalah adalah jaminan yang diberikan oleh penanggung (Kafil) kepada pihak ketiga untuk memenuhi kewajiban pihak kedua atau yang ditanggung.

\footnotetext{
${ }^{10}$ Muhammad Syafi'I Antonio, op.cit, h. 131
} 
$168\}$ Analisis Pengetahuan Nasabah tentang Produk Perbankan Syariah

c. Produk jasa (Service) $)^{11}$

1) Sharf (Jua beli valuta asing) Pada prinsipnya jual beli valuta asing sejalan dengan prinsip sharf. Jual beli mata uang yang tidak sejenis ini, penyerahannya harus dilakukan pada waktu yang sama (spot). Bank mengambil keuntungan dari jual beli valuta asing ini.

2) Ijarah (Sewa) Jenis kegiatan ijarah antara lain penyewahan kotak simpanan (safe deposit box) dan jasa tata laksana administrasi dokumen (custodian). Bank mendapat imbalan sewa dari jasa tersebut. $^{12}$

\section{Perbankan Syariah}

a. Pengertian perbankan syariah

Perbankan adalah suatu lembaga yang melaksanakan tiga fungsi utama yaitu menerima simpanan uang, meminjamkan uang dan jasa pengiriman uang. Secara sederhana bank diartikan sebagai lembaga keuangan yang dalam kegiatan usahanya adalah menghimpun dana dari masyarakat dan menyalurkannya kembali kepada masyarakat serta memberikan jasa-jasa bank lainnya. ${ }^{13}$

Bank Islam atau disebut bank syariah adalah bank yang beroperasi dengan tidak mengandalkan pada bunga. Bank Islam atau biasa disebut dengan bank tanpa bunga adalah lembaga keuangan atau perbankan yang beroperasional dan produknya dikembangkan berdasarkan pada Al-Qur'an dan Hadist.

b. Landasan hukum perbankan syariah

Pengakuan Bank Syariah secara yuridis normatif tercatat dalam peraturan perundang-undangan di Indonesia, di antaranya UndangUndang No.7 Tahun 1992 tentang Perbankan, Undang-Undang No.10 tentang Perubahan atas Undang-Undang No.7 Tahun 1998 tentang Perbankan, Undang-Undang No.3 Tahun 2004 tentang Perubahan atas Undang-Undang No.23 Tahun 1999 tentang Bank Indonesia, UndangUndang No. 3 Tahun 2006 tentang Perubahan atas Undang-Undang No. 7 Tahun 1989 tentang Peradilan Agama. ${ }^{14}$

${ }^{11}$ Heri sudarsono, Bank Dan Lembaga Keuangan Syariah, (Yogyakarta: Ekonosia, mei 2004),h. 35

${ }^{12}$ Adiwarman A. Karim, op.cit, edisi-ke4, h. 107

${ }^{13}$ Kasmir, Pemasaran Bank, (Jakarta: kencana, 2004), Edisi Revisi, cetakan ke-3, h.08

${ }^{14}$ Muhammad, Manajemen Bank Syariah, (Yogyakarta: UUP AMP YKPN, 2002), h. 2

...::: Malia: Jurnal Ekonomi Islam, Volume 10 Nomor 2 Juni 2019 :::... 
Bank Syariah dan Bank Muamalat serta bank konvensional yang membuka layanan syariah di Indonesia menjadikan pedoman UndangUndang No. 10 Tahun 1998 tentang Perubahan atas Undang-Undang No. 7 Tahun 1992 tentang Perbankan, Undang-Undang No.3 Tahun 2004 tentang Perubahan atas Undang-Undang No. 23 Tahun 1999 tentang Bank Indonesia. Undang-undang dimaksud yang kemudian di jabarkan dalam berbagai peraturan Bank Indonesia.

c. Akad-Akad perbankan syariah

Berikut adalah beberapa akad yang digunakan dalam bank syariah, yaitu:

\section{1) Mudharabah}

Secara teknis, mudharabah adalah sebuah akad kerjasama antar pihak, yaitu pihak pertama (shahibul maal) menyediakan seluruh (100\%) modal sedangkan pihak lainnya menjadi pengelola. ${ }^{15}$

2) Wadiah wadiah

Dapat juga diartikan titipan murni dari satu pihak ke pihak lain, baik sebagai individu maupun sebagai satu badan hukum. Titipan dimaksud, yang harus dijaga dan dikembalikan kapan saja si penitip menghendaki. ${ }^{16}$

3) Murabahah

Murabahah adalah jual beli barang pada harga asal dengan tambahan keuntungan yang disepakati dan tidak terlalu memberatkan calon pembeli. Dalam kontrak murabahah, penjual harus memberitahukan harga produk yang ia beli dan menentukan suatu tingkat keuntungan sebagai tambahannya. ${ }^{17}$

4) Musyarakah

Musyarakah adalah akad kerjasama antara dua pihak atau lebih untuk melakukan suatu usaha tertentu. Masing-masing pihak dalam melakukan usaha dimaksud, memberikan kontribusi dana (atau amal/ expertise) berdasar kesepakatan bahwa keuntungan dan risiko akan ditanggung bersama sesuai kesepakatan ketika melakukan akad. ${ }^{18}$

\footnotetext{
${ }^{15}$ Ali, Hukum..., h. 25

${ }^{16}$ Ibid, h. 23

${ }^{17}$ Ibid, h. 26

${ }^{18}$ Ibid, h. 28
} 
$170\}\{$ Analisis Pengetahuan Nasabah tentang Produk Perbankan Syariah

5) Salam

Salam adalah jual beli barang dengan cara pemesanan dengan syarat-syarat tertentu dan pembayaran tunai terlebih dahulu secara penuh. ${ }^{19}$

6) Istishna

Istishna Didefinisikan sebagai kegiatan jual beli barang dalam bentuk pemesanan pembuatan barang dengan kriteria dan persyaratan tertentu yang disepakati dengan pembayaran sesuai dengan kesepakatan.

7) Ijarah

Ijarah adalah transaksi sewa-menyewa atas suatu barang dan ata upah-mengupah atas suatu jasa dalam waktu tertentu melalui pembayaran sewa atau imbalan jasa. Ijarah juga dapat diinterpretasikan sebagai suatu akad pemindahan hak guna atas barang atau jasa melalui pembayaran upah sewa, tanpa diikuti dengan pemindahan kepemilikan (ownership/ milkiyah) atas barang itu sendiri. ${ }^{20}$

\section{HASIL PENELITIAN}

\section{Data Deskriptif}

a. Karakteristik Responden

Responden yang dimintai jawabannya atas instrumen pada penelitian ini berjumlah 30 orang yang menjadi nasabah di Bank Muamalat KCP Malang Kepanjen. Di bawah ini akan dijelaskan beberapa karakteristik responden berdasarkan jenis kelamin dan tingkat usia.

Tabel 1. Data Ditribusi Berdasarkan Jenis Kelamin

\begin{tabular}{|c|c|c|c|}
\hline No & Jenis kelamin & Jumlah Responden (orang) & Persentase \% \\
\hline 1 & Laki-Laki & 14 & $14 \%$ \\
\hline 2 & Perempuan & 16 & $16 \%$ \\
\hline \multicolumn{2}{|c|}{ Total } & 30 & $30 \%$ \\
\hline
\end{tabular}

19 Abdul Ghofur Anshori, Perbankan Syariah di Indonesia, Yogyakarta: Gadjah Mada University Press, 2009, h. 106

${ }^{20}$ Ibid, h. 120 .

...::: Malia: Jurnal Ekonomi Islam, Volume 10 Nomor 2 Juni 2019 :::... 
Tabel menunjukkan bahwa dari 30 orang didominasikan oleh perempuan yaitu sebanyak 16 orang atau setara dengan $16 \%$. Hal ini dikarenakan perempuan lebih pandai mengelola keuangan dan bisa menyisakan penghasilan untuk masa depan. Sedangkan nasabah berjenis kelamin laki-laki sebanyak 14 orang atau setara dengan $14 \%$. Hal tersebut dikarenakan laki-laki lebih boros dan kemungkinan lebih agresif dalam berinvestasi.

Tabel 2 Data Distribusi Berdasarkan Usia

\begin{tabular}{|c|c|c|c|}
\hline No & Usia & Jumlah Responden (orang) & Persentase \% \\
\hline 1 & $22-39$ & 22 & $22 \%$ \\
\hline 2 & $40-58$ & 5 & $5 \%$ \\
\hline 3 & $59-76$ & 3 & $3 \%$ \\
\hline \multicolumn{2}{|c|}{ Total } & 30 & $30 \%$ \\
\hline
\end{tabular}

Tabel menunjukkan bahwa usia responden nasabah Bank Muamalat KCP Malang Kepanjen didominasikan pada kisaran usia 2239 tahun yaitu sebanyak 22 orang atau setara dengan $22 \%$. Hal ini dikarenakan memudahkan transaksi dan memiliki sikap dan keyakinan tersendiri dalam menentukan pilihan. Sedangkan nasabah Bank Muamalat KCP Malang Kepanjen dengan kisaran usia 59-76 tahun yaitu sebanyak 3 orang atau setara dengan 3\%. Hal tersebut dikarenakan kurangnya mengetahui produk-produk di Bank muamalat KCP Malang Kepanjen.

b. Analisis Deskriptif

1) Data pengetahuan nasabah tentang pembiayaan Bank Muamalat KCP Malang Kepanjen dengan sistem bag hasil, jual-beli, agunan tunai.

Tabel 3. Pengetahuan nasabah tentang pembiayaan Bank Muamalat KCP

Malang Kepanjen dengan sistem bagi hasil, jual-beli, agunan tunai

\begin{tabular}{|c|c|c|c|}
\hline No & Alternatif Jawaban & Frekuensi & Presentase \% \\
\hline 1 & Sangat Setuju & 6 & $6 \%$ \\
\hline 2 & Setuju & 12 & $12 \%$ \\
\hline 3 & Netral & 11 & $11 \%$ \\
\hline 4 & Tidak Setuju & 1 & $1 \%$ \\
\hline 5 & Sangat Tidak Setuju & & \\
\hline \multicolumn{2}{|c|}{ Total } & 30 & $30 \%$ \\
\hline
\end{tabular}


$172\}\{$ Analisis Pengetahuan Nasabah tentang Produk Perbankan Syariah

Tabel menunjukkan jawaban dari pertanyaan "Pembiayaan Bank Muamalat KCP Malang Kepanjen dengan sistem bagi hasil, jualbeli, agunan tunai". Jumlah responden yang menyatakan sangat setuju 6 orang atau setara dengan $6 \%$, setuju sebesar 12 orang atau setara dengan $12 \%$, netral sebesar 11 orang atau setara dengan $11 \%$, tidak setuju sebesar 1 orang atau setara dengan $1 \%$.

Hal ini menunjukkan bahwa sebagian besar responden menyatakan setuju tentang pembiayaan Bank Muamalat KCP Malang Kepanjen menggunakan sistem bag hasil, jual-beli, agunan tunai. Hal ini dikarenakan bahwa sebagai nasabah mereka mengetahui tentang bagi hasil, jual-beli, agunan tunai, karena sistem ini yang membedakan dengan Bank Konvensional. Data pengetahuan nasabah tentang di dalam Bank Muamalat terdapat penyaluran dana zakat, infaq, shodaqoh (ZIS).

Tabel 4. Pengetahuan nasabah tentang Bank Muamalat terdapat penyaluran zakat, infaq, shodaqoh (ZIS)

\begin{tabular}{|c|c|c|c|}
\hline No & Alternatif Jawaban & Frekuensi & Presentase \% \\
\hline 1 & Sangat Setuju & 14 & $14 \%$ \\
\hline 2 & Setuju & 9 & $9 \%$ \\
\hline 3 & Netral & 7 & $7 \%$ \\
\hline 4 & Tidak Setuju & & \\
\hline 5 & Sangat Tidak Setuju & & $30 \%$ \\
\hline \multicolumn{2}{|c|}{ Total } & 30 & \\
\hline
\end{tabular}

Tabel menunjukkan jawaban dari pertanyaan "Di dalam Bank Muamalat terdapat penyaluran zakat, infaq, shodaqoh (ZIS)". Jumlah responden yang menyatakan sangat setuju 14 orang atau setara dengan $14 \%$, setuju sebesar 9 orang atau setara dengan 9\%, netral sebesar 7 orang atau setara dengan $7 \%$.

Hal ini menunjukkan bahwa sebagian besar responden menyatakan sangat setuju tentang Bank Muamalat terdapat penyaluran zakat, infaq, shodaqoh. Hal ini dikarenakan nasabah memahami betul bahwa Bank Muamalat melayani penyaluran dana zakat, infaq, shodaqoh.

2) Data pengetahuan nasabah tentang tentang Bank Muamalat tidak menggunakan instrumen bunga, spekulasi, dan sistem gharar.

Tabel 5. Bank Muamalat tidak menggunakan instrumen bunga, 
spekulasi, dan sistem gharar

\begin{tabular}{|c|c|c|c|}
\hline No & Alternatif Jawaban & Frekuensi & Presentase \% \\
\hline 1 & Sangat Setuju & 11 & $11 \%$ \\
\hline 2 & Setuju & 12 & $12 \%$ \\
\hline 3 & Netral & 6 & $6 \%$ \\
\hline 4 & Tidak Setuju & 1 & $1 \%$ \\
\hline 5 & Sangat Tidak Setuju & & \\
\hline & Total & 30 & $30 \%$ \\
\hline
\end{tabular}

Tabel menunjukkan jawaban dari pertanyaan "Tidak menggunakan instrumen bunga, spekulasi, dan sistem gharar". Jumlah responden yang menyatakan sangat setuju 11 orang atau setara dengan $11 \%$, setuju sebesar 12 orang atau setara dengan $12 \%$, netral sebesar 6 orang atau setara dengan $6 \%$, tidak setuju sebesar 1 orang atau setara dengan $1 \%$.

Hal ini menunjukkan bahwa sebagian besar responden menyatakan setuju tentang Bank Muamaat tidak menggunakan sistem bunga, spekulasi dan sistem gharar. Hal ini dikarenakan Bank Muamalat tidak menggunakan bunga, spekulasi, dan sistem gharar, karena Bank Muamalat menganut pada Al-Qur'an dan Hadist.

3) Data pengetahuan nasabah tentang pengetahuan produk tabungan, deposito dan giro.

Tabel 6 Mengetahui tentang produk tabungan, deposito, giro

\begin{tabular}{|c|c|c|c|}
\hline No & Alternatif Jawaban & Frekuensi & Presentase $\%$ \\
\hline 1 & Sangat Setuju & 10 & $10 \%$ \\
\hline 2 & Setuju & 11 & $11 \%$ \\
\hline 3 & Netral & 7 & $7 \%$ \\
\hline 4 & Tidak Setuju & 2 & $2 \%$ \\
\hline 5 & Sangat Tidak Setuju & & \\
\hline & Total & 30 & $30 \%$ \\
\hline
\end{tabular}

Tabel menunjukkan jawaban dari pertanyaan "mengetahui tentang produk tabungan, deposito, giro". Jumlah responden yang menyatakan sangat setuju 10 orang atau setara dengan $10 \%$, setuju sebesar 11 orang atau setara dengan $11 \%$, netral sebesar 7 orang atau setara dengan $7 \%$, tidak setuju sebesar 2 orang atau setara dengan $2 \%$.

Hal ini menunjukkan bahwa sebagian besar responden menyatakan setuju tentang pengetahuan produk tabungan, deposito, 
$174\}\{$ Analisis Pengetahuan Nasabah tentang Produk Perbankan Syariah

giro. Hal ini dikarenakan bahwa sebagian besar nasabah sangat mengetahui produk tabungan, deposito, dan giro di Bank Muamalat.

4) Data pengetahuan nasabah tentang pengetahuan penyimpanan dana di Bank Muamalat dalam mata uang rupiah maupun valas adalah giro wadiah

Tabel 7. Mengetahui tentang penyimpanan dana di Bank Muamalat dalam mata uang rupiah maupun valas adalah giro wadiah

\begin{tabular}{|c|c|c|c|}
\hline No & Alternatif Jawaban & Frekuensi & Presentase \% \\
\hline 1 & Sangat Setuju & 9 & $9 \%$ \\
\hline 2 & Setuju & 7 & $7 \%$ \\
\hline 3 & Netral & 11 & $11 \%$ \\
\hline 4 & Tidak Setuju & 3 & $3 \%$ \\
\hline 5 & Sangat Tidak Setuju & & \\
\hline & Total & 30 & $30 \%$ \\
\hline
\end{tabular}

Tabel menunjukkan jawaban dari pertanyaan "mengetahui tentang penyimpanan dana di Bank Muamalat dalam mata uang rupiah maupun valas adalah giro wadiah". Jumlah responden yang menyatakan sangat setuju 9 orang atau setara degan 9\%, setuju sebesar 7 orang atau setara dengan $7 \%$, netral sebesar 11 orang atau setara dengan $11 \%$, tidak setuju sebesar 3 orang atau setara dengan $3 \%$.

Hal ini menunjukkan bahwa sebagian besar responden menyatakan netral tentang mengetahui tentang penyimpanan dana di Bank Muamalat dalam mata uang rupiah maupun valas adalah giro wadiah. Hal ini dikarenakan nasabah masih belum faham betul tentang penyimpanan dana di bank Muamalat dalam mata uang rupiah maupun valas adalah giro wadiah.

5) Data pengetahuan nasabah tentang salah satu produk Bank Muamalat adalah tabungan iB Hijrah.

Tabel 8 salah satu produk Bank Muamalat adalah tabungan iB Hijrah

\begin{tabular}{|c|c|c|c|}
\hline No & Alternatif Jawaban & Frekuensi & Presentase \% \\
\hline 1 & Sangat Setuju & 11 & $11 \%$ \\
\hline 2 & Setuju & 14 & $14 \%$ \\
\hline 3 & Netral & 4 & $4 \%$ \\
\hline 4 & Tidak Setuju & 1 & $1 \%$ \\
\hline 5 & Sangat Tidak Setuju & & \\
\hline & Total & 30 & $30 \%$ \\
\hline
\end{tabular}


Tabel menunjukkan jawaban dari pertanyaan "salah satu produk Bank Muamalat adalah tabungan iB Hijrah". Jumlah responden yang menyatakan sangat setuju 11 orang atau setara dengan $11 \%$, seuju sebesar 14 orang atau setara dengan $14 \%$, netral sebesar 4 orang atau setara dengan $4 \%$, tidak setuju sebesar 1 orang atau setara dengan $1 \%$.

Hal ini menunjukkan bahwa sebagian besar responden menyatakan setuju tentang salah satu produk Bank Muamalat adalah tabungan iB Hijrah. Hal ini dikarenakan bahwa sebagian besar nasabah mengetahui tentang iB Hijrah dan nasabah tidak ragu lagi tentang produk iB Hijrah di Bank Muamalat tersebut.

6) Data pengetahuan nasabah tentang mengetahui tentang produk pembiayaan

Tabel 9 mengetahui tentang produk pembiayaan

\begin{tabular}{|c|c|c|c|}
\hline No & Alternatif Jawaban & Frekuensi & Presentase $\%$ \\
\hline 1 & Sangat Setuju & 10 & $10 \%$ \\
\hline 2 & Setuju & 8 & $8 \%$ \\
\hline 3 & Netral & 9 & $9 \%$ \\
\hline 4 & Tidak Setuju & 3 & $3 \%$ \\
\hline 5 & Sangat Tidak Setuju & & \\
\hline & Total & 30 & $30 \%$ \\
\hline
\end{tabular}

Tabel menunjukkan jawaban dari pertanyaan "mengetahui tentang produk pembiayaan". Jumlah responden yang menyatakan sangat setuju 10 orang atau setara dengan $10 \%$, setuju sebesar 8 orang atau setara dengan $8 \%$, netral sebesar 9 orang atau setara dengan $9 \%$, tidak setuju sebesar 3 orang atau setara dengan $3 \%$.

Hal ini menunjukkan bahwa sebagian besar responden menyatakan sangat setuju tentang mengetahui produk pembiayaan. Hal ini dikarenakan nasabah merasa sangat tertolong dengan adanya produk pembiayaan di Bank Muamalat karena di produk pembiayaan ada 3 macam produk yaitu KPR, Pensiun, multiguna.

7) Data pengetahuan nasabah tentang mengetahui tentang produk tabungan

Tabel 10 mengetahui tentang produk tabungan

\begin{tabular}{|c|c|c|c|}
\hline No & Alternatif Jawaban & Frekuensi & Presentase \% \\
\hline 1 & Sangat Setuju & 9 & $9 \%$ \\
\hline
\end{tabular}


$176\}\{$ Analisis Pengetahuan Nasabah tentang Produk Perbankan Syariah

\begin{tabular}{|c|c|c|c|}
\hline 2 & Setuju & 14 & $14 \%$ \\
\hline 3 & Netral & 4 & $4 \%$ \\
\hline 4 & Tidak Setuju & 3 & $3 \%$ \\
\hline 5 & Sangat Tidak Setuju & & \\
\hline & Total & 30 & $30 \%$ \\
\hline
\end{tabular}

Tabel menunjukkan jawaban dari pertanyaan "mengetahui tentang produk tabungan". Jumlah responden yang menyatakan sangat setuju 9 orang atau setara dengan $9 \%$, setuju sebesar 14 orang atau setara dengan $14 \%$, netral sebesar 4 orang atau setara dengan $4 \%$, tidak setuju sebesar 3 orang atau setara dengan $3 \%$.

Hal ini menunjukkan bahwa sebagian besar responden menyatakan setuju tentang mengetahui produk tabungan. Hal ini dikarenakan bahwa sebagai nasabah mereka mengetahui tentang produk tabungan dan mereka sangat nyaman, menguntungkan, membawa berkah dlam melakukan menabung di Bank Muamalat tersebut.

8) Data pengetahuan nasabah tentang mengetahui tentang produk giro

Tabel 11 mengetahui tentang produk giro

\begin{tabular}{|c|c|c|c|}
\hline No & Alternatif Jawaban & Frekuensi & Presentase \% \\
\hline 1 & Sangat Setuju & 8 & $8 \%$ \\
\hline 2 & Setuju & 9 & $9 \%$ \\
\hline 3 & Netral & 10 & $10 \%$ \\
\hline 4 & Tidak Setuju & 3 & $3 \%$ \\
\hline 5 & Sangat Tidak Setuju & & \\
\hline & Total & 30 & $30 \%$ \\
\hline
\end{tabular}

Tabel menunjukkan jawaban dari pertanyaan "mengetahui tentang produk giro". Jumlah responden yang menyatakan sangat setuju 8 orang atau setara dengan $8 \%$, setuju sebesar 9 orang atau setara dengan $9 \%$, netral sebesar 10 orang atau setara dengan $10 \%$, tidak setuju sebesar 3 orang atau setara dengan $3 \%$.

Hal ini menunjukkan bahwa sebagian besar responden menyatakan netral tentang mengetahui produk giro. Hal ini dikarenakan nasabah belum begitu faham terkait produk giro dan masih jarang nasabah memakai produk giro. 


\section{PEMBAHASAN}

Berdasarkan analisis yang diuraikan di atas, maka secara keseluruhan pembahasan hasil penelitian analisis pengetahuan nasabah tentang produk perbankan syariah di Bank Muamalat KCP Malang Kepanjen adalah sebagai berikut:

Pengetahuan nasabah merupakan suatu tindakan yang berhubungan dengan pola pikir seseorang yang mempengaruhi minat. Hasil dari penelitian menunjukkan bahwa nasabah cenderung faham terkait produk-produk di Bank Muamalat KCP Malang Kepanjen dan signifikan terhadap minat menabung, deposito, giro, pembiayaan di Bank Muamalat KCP Malang Kepanjen.

Semakin banyak pengetahuan nasabah tentang produk-produk perbankan syariah maka semakin meningkat minat menabung, deposito, giro, pembiayaan nasabah di Bank Muamalat KCP Malang Kepanjen itu sendiri, begitu pula sebaliknya semakin sedikit pengetahuan nasabah tentang produkproduk perbankan syariah di Bank Muamalat KCP Malang Kepanjen maka semakin menurun minat menabung, deposito, giro, pembiayaan nasabah di Bank Muamalat KCP Malang Kepanjen.

Dengan adanya tabungan iB Hijrah ini sangat memudahkan nasabah untuk bertransaksi di Bank Muamalat KCP Malang Kepanjen dan nasabah sangat senang karena produk iB Hijrah sangat membantu permasalahan nasabah tersebut. Hal ini membuat nasabah semakin tertarik untuk menabung, deposito, giro, pembiayaan di Bank Muamalat KCP Malang Kepanjen.

Pengetahuan nasabah adalah semua informasi-informasi yang dimiliki nasabah mengenai berbagai macam produk dan jasa serta pengetahuan lainnya yang terkait dengan produk dan jasa tersebut dan informasi yang berhubungan dengan fungsinya produk dan jasa sebagai nasabah.

Berdasarkan uraian diatas dengan adanya pengetahuan akan suatu produk Bank Muamalat KCP Malang Kepanjen berpengaruh terhadap minat nasabah menabung, deposito, giro, pembiayaan. Dari segi persepsi yang baik terhadap Bank Muamalat KCP Malang Kepanjen dapat diraih dengan adanya sosialisasi maupun bauran promosi. Suatu pengetahuan akan keunggulan, kebaikan, kelebihan produk Bank Muamalat KCP Malang Kepanjen akan menambah minat nasabah maupun masyarakat yang bukan nasabah dalam berhubungan dengan perbankan syariah. 
$178\}\{$ Analisis Pengetahuan Nasabah tentang Produk Perbankan Syariah

\section{KESIMPULAN}

Bank bukanlah suatu hal yang asing bagi masyarakat di negara maju. Masyarakat di negara maju sangat membutuhkan keberadaan bank. Bank dapat dianggap sebagai suatu lembaga keuangan yang aman dalam melakukan berbagai macam aktivitas keuangan. Bank merupakan salah satu lembaga yang mempunyai peran penting dalam mendorong pertumbuhan perekonomian suatu negara, bahkan pertumbuhan bank di suatu negara dipakai sebagai ukuran pertumbuhan perekonomian negara tersebut. Bankbank Islam dikembangkan berdasarkan prinsip yang tidak membolehkan pemisahan antara hal yang temporal (keduniaan) dan keagamaan. Prinsip ini mengharuskan kepatuhan kepada syariah sebagai dasar dari semua aspek kehidupan. Peneliti menyimpulkan bahwa pengetahuan nasabah mengenai produk lebih tinggi dibanding pengetahuan nasabah mengenai pembelian dan pemakaian. Sedangkan pengetahuan nasabah mengenai pembelian lebih rendah dibanding pengetahuan nasabah mengenai produk dan pemakaian. Selain itu, pengetahuan nasabah berpengaruh positif dan signifikan terhadap keputusan menjadi nasabah pada Bank Muamalat KCP Malang Kepanjen.

\section{DAFTAR PUSTAKA}

Adiwarman A. Karim, Bank Islam Analisa Fiqih Dan Keuangan, Jakarta: PT Raja Grafindo Pers, September 2004.

Amir Machmud, Rukmana, Bank Syariah Teori, Kebijakan, Dan Studi di Indonesia, Jakarta: Gelora Aksara Pratama, 2010.

Andrian Sutedi, Pasar Modal Syariah Jakarta: Sinar Grafika, 2011.

Ascarya, Akad \& Produk Bank Syariah, Jakarta: PT Raja Grafindo Persada, 2008.

Ascarya, Akad \& Produk Bank Syariah, Jakarta: PT Raja Grafindo Persada, 2008.

Heri sudarsono, Bank Dan Lembaga Keuangan Syariah, Yogyakarta: Ekonosia, mei 2004.

Ismail, Manajemen Perbankan Dari Teori Menuju Aplikasi, Jakarta: Kencana, 2010.

Ismail, Manajemen Perbankan Dari Teori Menuju Aplikasi, Jakarta: Kencana, 2010.

Kasmir, Pemasaran Bank, Edisi Revisi, cetakan ke-3 Jakarta: kencana, 2004. Latifa M. Alqaoud dan Mervyn K. Lewis, Perbankan Syariah, Jakarta: PT Serambi Ilmu Semesta, 2001. 
Mawardi, Ekonomi Islam, Pekanbaru: Alaf Riau, 2007.

Muhammad Syafi'I Antonio, Bank Syariah Dari Teori Ke Praktek, Jakarta: Gema Insani Press, 2001.

Muhammad Syafi'I Antonio, Bank Syariah Dari Teori Ke Praktek, Jakarta: Gema Insani Press, 2001.

Selamet Wiyono, Cara Mudah Memahami Akuntasi Syariah, Jakarta: PT Gramedia Widiasarana Indonesia, 2005. 
$180\}$ Analisis Pengetahuan Nasabah tentang Produk Perbankan Syariah ..::: Malia: Jurnal Ekonomi Islam, Volume 10 Nomor 2 Juni 2019 :::... 